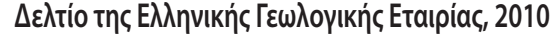

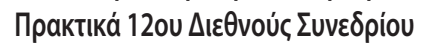

Пátpa, Máıǫ 2010
Bulletin of the Geological Society of Greece, 2010

Proceedings of the 12 th International Congress

Patras, May, 2010

\title{
PETROLOGICAL INVESTIGATION OF CARBONATE ROCKS FROM THE IONIAN ZONE (ETOLOAKARNANIA, WESTERN GREECE)
}

\author{
Bourouni P., Tsikouras B., and Hatzipanagiotou K. \\ University of Patras, Department of Geology, Section of Earth Materials, 26500 Patras, Greece, \\ bourouni@upatras.gr,v.tsikouras@upatras.gr,k.hatzipanagiotou@upatras.gr
}

\begin{abstract}
The petrographic features of the carbonate rocks from the Ionian Zone in the Etoloakarnania Prefecture are presented. They are represented by limestones with minor dolomite. The limestones include: (i) wackestones (or sparse micrites), with poor presence of allochems within a mud matrix; (ii) packstones (or packed micrites) with increasing levels of carbonate grains that are still surrounded by micrite matrix, and (iii) grainstones (or sparites) containing allochems that are cemented with sparry calcite crystals, while the mud matrix is absent. Bioclasts are the dominant carbonate components in most of the samples accompanied by infrequent pelloids, intraclasts, lithoclasts and ooids. Crystalline limestones were not identified. Quartz, apatite, barite, anhydrite, halite, clay minerals, magnetite and ilmenite have been determined as accessory phases. The results show that mineralogical and petrographic features of the analyzed carbonate rocks are related to their evolution during the development of the Ionian Zone from a shallow-marine platform to a deep-water basin.
\end{abstract}

Key words: carbonate rocks, limestone, fabric, Ionian Zone, western Greece.

\section{Introduction}

Ranging in age from Precambrian to Holocene, carbonate rocks are present virtually throughout the world. Limestone contains principally calcite, with or without dolomite. Aragonite and magnesian calcite are abundant primary minerals in recent marine carbonate sediments and limestones. Both are metastable, tending to alter to stable calcite or low-magnesian calcite with burial. Limestone is a common sedimentary rock and one of the most useful and versatile of all industrial materials, having variable applications such as in chemical and metallurgical industries, as construction material, for glass and ceramics, in the production of cement, as filler in paper, plastics and paint industry and for soil treatment. Along with dolomite, limestone comprises about $15 \%$ of all sedimentary rocks and although they consist only $2 \%$ of the whole of crustal rocks per volume, in Greece they cover $70 \%$ of its total surface (Carr et al., 1994).

The Etoloakarnania Prefecture consists principally of various series of carbonate rocks. The present study aims in describing the carbonate rocks of the Ionian Zone of Etoloakarnania, to investigate their depositional environment and to evaluate their properties for their uses as industrial rocks.

\section{Geological setting}

The Etoloakarnania Prefecture is located in continental Western Greece and consists, from West to East, of the Ionian, Gavrovo-Tripolitza and Olonos-Pindos geotectonic Zones (Fig.1). Continuous 


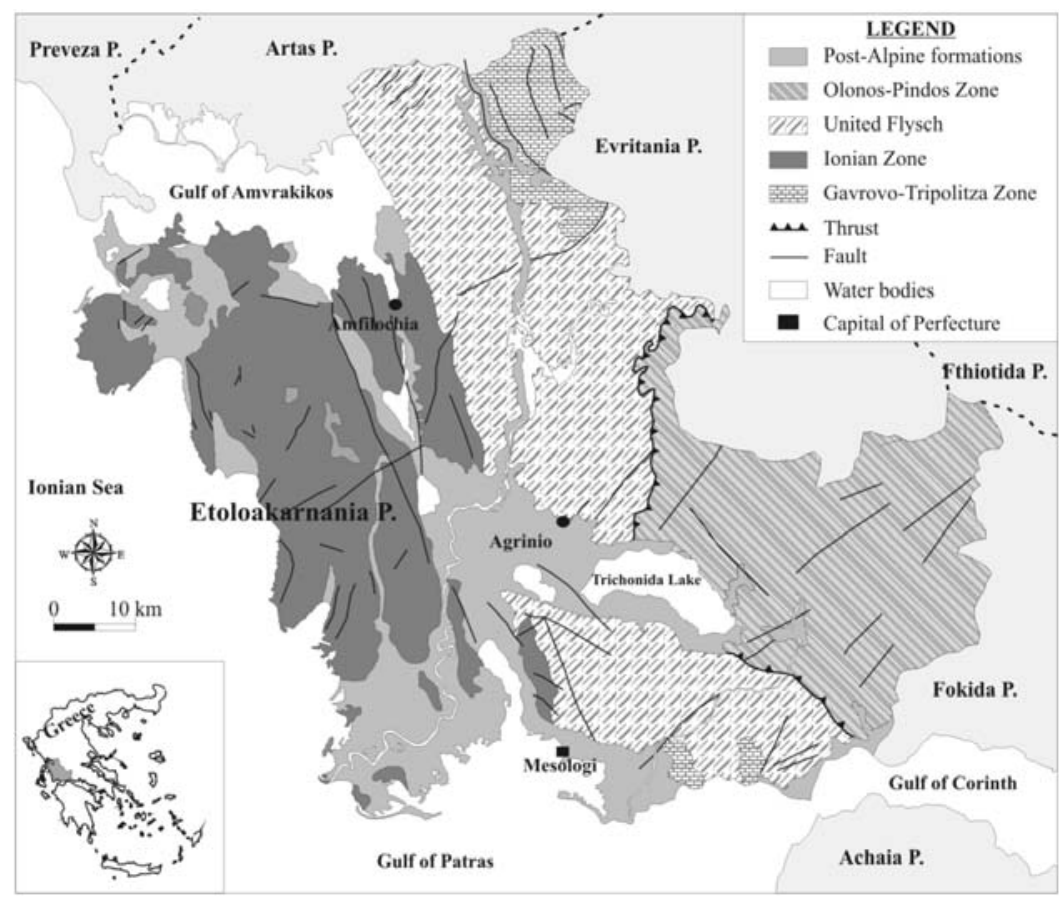

Fig. 1: Map showing the geotectonic units occurring in Etoloakarnania Prefecture (after Bornovas and Rodoyanni-Tsiabaou, 1983).

sedimentation prevailed throughout the Mesozoic and Tertiary; hence thick successions of carbonate rocks cover the major part of the study area. The Gavrovo-Tripolitza Zone includes shallow platform carbonate rocks of Cretaceous-Eocene age which are covered by vast quantities of clastic sediments (De Wever, 1975; Fleury, 1980) whereas the Pindos zone reflects an oceanic basin at the easternmost part of the Etoloakarannia. The Mesozoic series of the Pindos basin consists typically of deep-water sediments which together with the clastic sediments of flysch form a thick succession (Smith et al., 1975, 1979; Jones, 1990; Robertson et al., 1991; Degnan, 1992; Robertson, 1994, Degnan and Robertson, 1998).

During the Mesozoic the Ionian zone corresponded to a vast, intra-platform rift basin bounded on both sides by shallow platforms; the Apulia platform on the west and Gavrovo-Tripolitza platform on the east (Aubouin, 1959; Katsikatsos, 1992; Bosellini and Morsilli, 1997). The early shallow character, of the Ionian basin, during the pro-rift period, is reflected on its older rocks which include the Permian-Triassic evaporites and dolomites, and the neritic Pantokrator limestones of Upper Triassic age, which chiefly extend on the west part of the study area. During the following rift period (Lower Jurassic - Upper Jurassic), the Lower siliceous shales with Posidonomya, the red-blue, limestones with ammonites (Ammonitico Rosso), the filamentous limestones and the Upper siliceous shales with Posidonomya are deposited (Renz, 1955) (Fig 2). The syn-rift formations are overlain by the Upper Jurassic - Lower Cretaceous pelagic Vigla Limestone Formation (Aubouin, 1959; Karakitsios and Koletti, 1992; Karakitsios et al., 2004), the Upper Cherts (BP 1971, IFP-IGRS 1966) the pelagic and microbrecciated limestones of Senonian and Paleocene-Eocene limestones. The upper members are covered by flysch deposits of Eocene age (Zelilidis et al., 2003) (Fig. 2). West- 


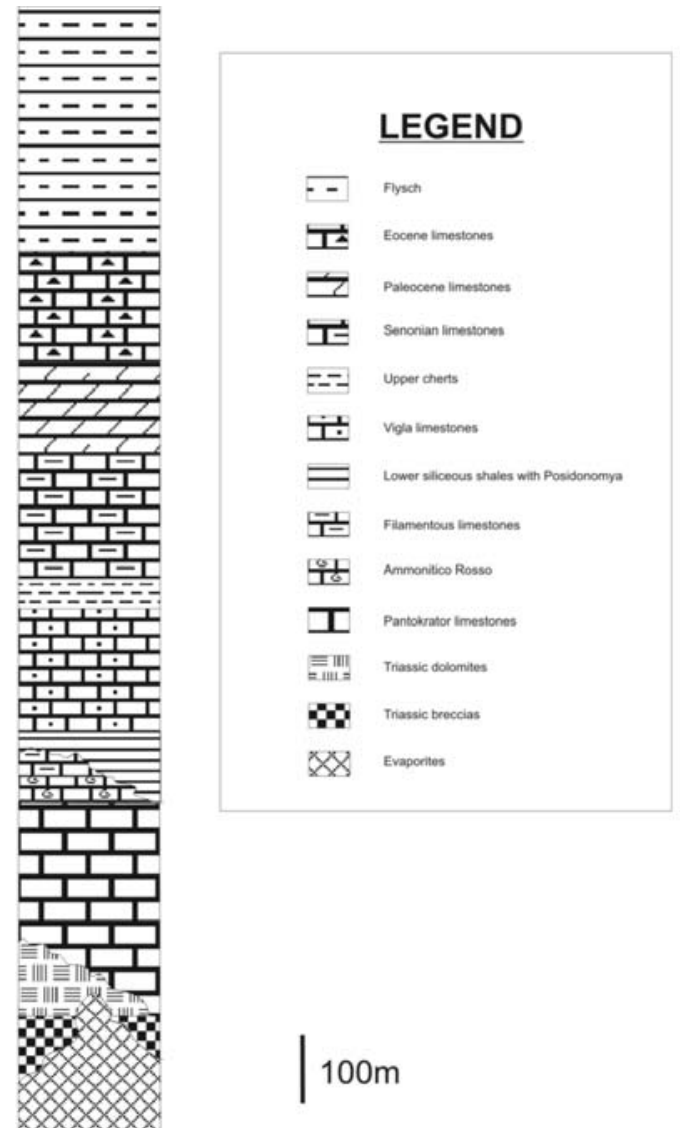

Fig. 2: Stratigraphic column of the Ionian Zone formations in Etoloakarnania area.

wards emplacement and successive overthrust resulted in a series of nappes of Gavrovo-Tripolitza and Pindos Zones onto the Ionian Zone along with deformation of the Pindos and formation of a series of thrust sheets (Robertson and Degnan, 1997).

\section{Analytical methods}

Electron microanalyses were carried out on polished thin sections at the Laboratory of Electron Microscopy and Microanalysis, University of Patras. All elements were analyzed by an electron-dispersive X-rays (EDX), using EDS and WDS detectors attached to a JEOL JSM-6300 SEM. The calibration of the instrument was made with well characterized reference materials (including natural minerals, synthetic glass and metal). Operating conditions were accelerating voltage $20 \mathrm{kV}$ and beam current $0.9 \mathrm{nA}$ with $4 \mu \mathrm{m}$ diameter beam. The total counting time was $60 \mathrm{sec}$ and dead time $40 \%$. Detection limits are $\sim 0.1 \%$ and accuracy better than $5 \%$ was obtained.

Whole rock chemical analyses were performed at ACTLABS, Ancaster, Ontario, by fusion ICPOES for major elements and combined ICP-MS and INAA for trace elements. Detection limit for major elements is $0.01 \%$, except for $\mathrm{TiO}_{2}$ which is $0.005 \%$. Replicate analyses suggest accuracy 
better than $5 \%$ for major elements and most trace elements. The determination of $\mathrm{CO}_{2}$ was accomplished by coulometry.

\section{Macroscopic description}

Field work in the carbonate rocks of the Ionian Zone showed that Triassic dolomites are massive and unbedded, with compact, grainy texture and gray colour. The overlying Pantokrator limestones form unbedded to very thick bedded, homogenous outcrops (Fig. 2). It comprises white to whitish or gray to dark gray, fine crystalline rocks with visible carbonate components. Small, window-like, cavities which are filled by secondary, crystalline calcite are frequently observed. The Vigla Limestone formation displays thin to medium platy outcrops with intercalations of grayish to dark-gray nodules or beds of cherts, indicating the change of the depositional conditions from neritic to pelagic, as the Ionian zone evolves to a deep basin. This massive limestone has cream, yellowish, and whitish colors, often with Fe-oxides impregnations. Calcite veins or fracture discontinuities are rare or absent. Bedding is not present in any of these biomicrites. The collected samples from the Senonian limestones show large variability. This is due to variable material deposited during clastic and pelagic processes that operated at the edges and central area of the Ionian zone. Representative samples of this formation comprise: a) cream to whitish, massive micrites, with well shaped dendritic depositions of oxides, stamped on their planar interfaces, b) light gray, grainy limestones with discernible carbonate components, weakly orientated to parallel directions and c) brecciated, light gray to whitish limestones, composed by an agglomerate of grains and fragments of various sizes and shapes which are cemented in a micritic matrix. The Paleocene limestone includes fossiliferous, whitish micrites, accompanied by rare nodules of gray cherts, red-brownish Fe-oxides and stylolites, as well as finecrystalline, gray limestones. The carbonate succession of the Ionian zone is completed with Eocene limestones, which include cream to whitish, homogenous micrites and light gray, microcrystalline, laminated limestones. Stylolites and rare depositions of opaque minerals occur in both types and cross-cut their almost pure carbonate mass (Fig. 2).

\section{Petrography}

Thin sections from 30 samples were prepared and observed through a polarizing microscope: the classification schemes by Dunham $(1962)$ and by Folk $(1959,1962)$ have been used for the description of the microscopic features of the collected samples. For clarity and simplicity, classification according to Folk is given in brackets, below. Although carbonate rocks are variable in composition, their components can be broadly divided into four main groups: non-skeletal grains, skeletal grains, micrite matrix and cement.

Limited outcrops of Triassic dolomites and dolomitic limestones, at the base of the zone, enabled us to collect only one sample. Microscopic examination reveals that the original structure has not been completely obliterated, so these dolomites can be described in terms of Dunham's (1962) and Folk's $(1959,1962)$ classification (preceded by the word dolomitic). Thus, this sample is a dolomitic peloidal grainstone or a dolomitic unsorted pelsparite, respectively. The majority of carbonate grains constitute pelloids, micritic, rounded to weakly elliptical in cross section, varying in size between 0.05-0.4 mm (Fig. 3a). Minor, thin-walled, bioclasts occur, too; their identification is not always easy because of dolomitization. The grains are cemented with fine $(10 \mu \mathrm{m})$, anhedral dolomite crystals, which form a xenotopic mosaic while micrite matrix is absent (Fig. 3a). Dolomitization is not fabric selective, as allochems and matrix have all been replaced by dolomite; rare calcite crystals have escaped dolomitization. Thin calcite veinlets also cross-cut the rocks. 
The Pantokrator limestones include:

a) Bioclastic wackestones (sparse biomicrites), composed predominately of micrite matrix that supports larger, sparsely distributed bioclasts. Scanning electron microscopic study aims in verifying that the carbonate matrix consists of microspar calcite crystals, ranging in size from $4 \mu \mathrm{m}$ up to $10 \mu \mathrm{m}$, forming a patchy developed, coarser mosaic of anhedral crystals (Fig. 3b). The skeletal fragments possess a dark micrite envelope around the grains, which is produced mostly by the boring activity of endolithic bacteria and they lack well preserved original structure, as their internal chambers are filled by equant, drusy sparite.This fact and their small size renders the identification of bioclasts difficult. The cavities filled with sparry calcite are frequently observed (Fig. $3 \mathrm{c}$ ). Veinlets of calcite and stylolites are often associated with insoluble material (mainly clay minerals) accumulated as a result of pressure-induced dissolution, interrupt the samples at any orientation.

b) Oobioclastic grainstones/packstones (unsorted oobiosparites/packed biomikrites). Abundant grains are observed within these limestones, such as bioclasts (e.g. green algae, foraminifera and gastropods with thin micrite walls and not always obvious chambering), ooids, pelloids (wholly micritized equigranular grains), and intraclasts. Although the observed ooids have been micritized they are still recognizable by their almost perfect circular shape, their size (about $0.45 \mathrm{~mm}$ ) and their weak, residual, concentric structure. Lithoclastic fragments of carbonate rocks, completely different from the host limestone, are rarely detected. The observed grainstones lack carbonate mud and allochems are cemented mostly by equant sparite crystals. However in places, probable micrite matrix exists in interstices. Calcite veins and stylolites occur, too. Small crystals of $\mathrm{Fe}$ oxides are also present in trace amounts.

The Vigla Limestone samples are classified as bioclastic wackestones (sparse biomicrites) and comprise locally porous, well indurated carbonate mud with small bioclasts suspended in it (Fig. 3d). The matrix is not completely dark and has undergone weak aggrading neomorphism leading in a relatively coarser mosaic. The micrite matrix is also loaded with homogenously, distributed very-fine silica crystals. The bioclasts have circular or elliptic shape and drusy sparite infilling. Small voids are detected within the fossils (intraparticle porosity), whereas in some cases bioclasts have completely dissolved out leaving a biomouldic porosity. No evidence of compaction was observed. Scanning electron microscopic examination confirmed the presence of Fe-oxides and quartz.

The textural variety observed in the Senonian limestones is also expressed in their microscopic features; their classification suggested the presence of:

- bioclastic wackestones (sparse biomicrites), with small bioclasts, mainly multi-chambered foraminifera "floating" in carbonate mud;

- bioclastic grainstones/packstones (unsorted biosparites/packed biomicrites) with bioclasts and intraclasts cemented with crystalline calcite. Tabular-shaped, bioclastic fragments now composed of fibrous calcite occur, probably as a result of calcitization of former aragonite that allowed the preservation of the fibrous structure (Fig. 3e). Minor amounts of anhydrite, apatite, halite and clay minerals were detected by electron microscopic observation (Fig. 3f).

- lithoclastic packstones (packed extramicrites), where fragments of limestones, with texture different relative to their host biomicrite matrix, supporting an out of depositional basin provenance for them.

The Paleocene limestones include bioclastic wackestones (sparse biomicrites) and bioclastic grain- 

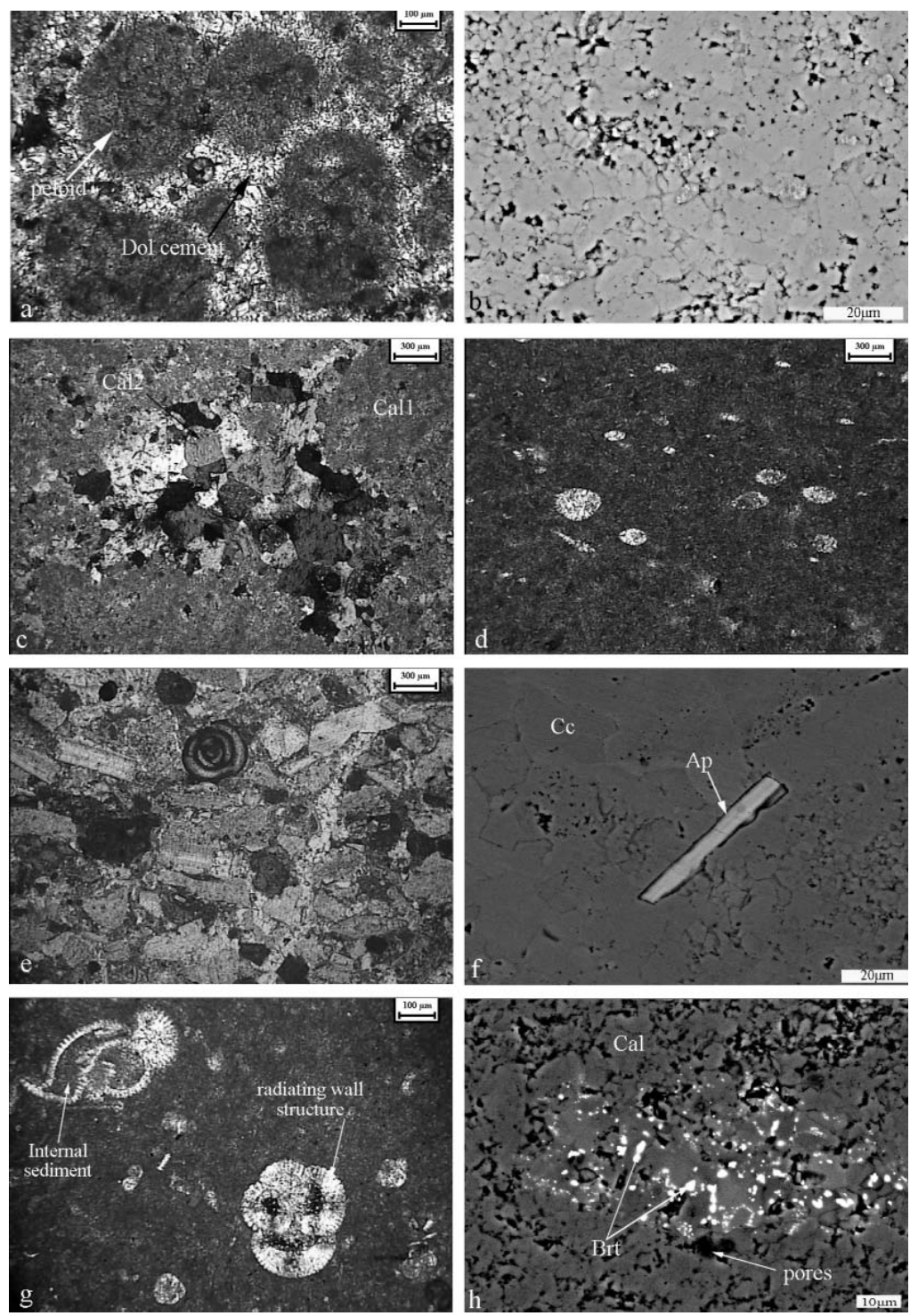

Fig. 3: (a) Photomicrograph showing peloids cemented by fine-crystalline dolomitic cement from sample AIT37 (crossed polarized light). (b) Back scattered electron image illustrating microspar which has resulted from the aggrading neomorphism of the micrite in sample AIT26. The neomorphic spar crystals are characterized by irregular or curved intercrystalline boundaries with embayments and irregular crystal-size distribution. Dark areas represent intercrystalline porosity. (c) Photomicrograph showing the characteristic cavities observed in Pantokrator limestones (sample AIT26). Calcite occupies the cavities (Cal2) exhibits a drusy fabric, characterized by increasing crystal size away from the cavity wall towards the cavity centre. The cavity is surrounded by micrite matrix (Cal1) (crossed polarized light). (d) Wackestone with sparse bioclasts from Vigla limestone formation. Photomicrograph from sample AIT35 (plane polarized light). (e) Photomicrograph showing abundant bioclasts and few endoclasts (dark micrite pieces) that produce a grain supported texture (sample AIT32b) (plane polarized light). (f) Back scattered electron image showing an apatite crystal in sample AIT32b. (g) Well preserved foraminifera floating in opaque micrite matrix. Photomicrograph from sample AIT46a (crossed polarized light). (h) Back scattered electron image showing anhedral barite crystals detected in sample AIT34a. 
stones (unsorted biosparites). The wackestones contain bioclasts, dominantly foraminifera rooted in the carbonate mud matrix. The bioclasts may have either thin walls, occasionally broken, filled with internal sediment and/or fine crystalline calcite, or thick walls, displaying well preserved radiating structure of fibrous crystals, with sparite infilling. The micrite matrix is opaque and uniform (Fig. $3 \mathrm{~g}$ ). The grainstones usually contain well-preserved, undamaged, sizeable fossils (mainly mollusks and benthonic foraminifera). Rare ooids showing well concentric structure and uniaxial extinction have been observed. Grains consisting exclusively of micrite probably represent micritized bioclasts. Usually, long axes of fossils are preferentially orientated parallel to sedimentary bedding. The grainstones are totally devoid of micrite matrix and their carbonate constituents produce a poorly sorted, grain supported texture.

The Eocene limestones comprise bioclastic wackestones (sparse biomicrites) and bioclastic packstones (packed biomicrites) with characteristics similar to those rock-types described for the Paleocene limestones. The majority of allochems constitute bioclasts, mainly well-preserved foraminifera, composed of fine-crystalline sparite and carbonate mud. The micrite matrix of the wackestones is not completely dark and exhibits a very-fine-crystalline texture, as a result of aggrading neomorphism. This diagenetic process resulted in the development of fine-crystalline calcite along subparallel zones with fuzzy margins with the micrite matrix. The packstones are sorted and in a few cases potential intraclasts of micrite are rarely detected. Trace amounts of apatite, quartz and micron-sized, anhedral crystals of barite, Fe-oxides and ilmenite are present within the wackestones and packstones (Fig. 3h).

\section{Mineral chemistry}

Representative microanalyses of the main constituents of the carbonate rocks are given in Table 1 . Several grains and crystals were analyzed, and in some cases each grain was analyzed from rim to core. The dominant rock forming mineral calcite may be termed, depending on the magnesium content, as low-Mg calcite with less than 4 mol. $\% \mathrm{MgCO}_{3}$ (molar $\mathrm{MgCO}_{3}$ ranges typically from 0.45 to 1.80 ). In a similar way, iron content of the studied samples show Fe-poor calcite compositions, as $\mathrm{Fe}_{2} \mathrm{O}_{3}{ }^{\mathrm{t}}$ is below detection limit in most of the samples (with few exceptions), thus the calcite is characterized as non-ferroan.

The analyzed calcite crystals from the collected rocks have $\mathrm{CaO}$ contents that range from 53.08 to $56.52 \%$. Some crystals show limited substitution of $\mathrm{Mg}$ for $\mathrm{Ca}$ with $\mathrm{MgO}$ ranging from 0.18 to 0.72 $\%$. In general, the Pantokrator limestone contains the purest calcite crystals relative to those from the other formations. Calcite crystals from cement and in veins are richer in $\mathrm{CaO}$ relative to the calcite analysed in grains and matrix. Few impurities include mainly few amounts of $\mathrm{K}_{2} \mathrm{O}, \mathrm{MgO}, \mathrm{Na}_{2} \mathrm{O}$ and $\mathrm{SiO}_{2}$ in the analyzed calcites. $\mathrm{K}_{2} \mathrm{O}$ content ranges from 0.10 to $0.28 \%$ whereas $\mathrm{Na}_{2} \mathrm{O}$ is relatively higher $(0.18-0.48 \%)$. $\mathrm{SiO}_{2}$ ranges from 0.21 to $0.35 \%$ particularly in the micrite carbonate matrix or to a lesser extent in micritized grains, mainly in the Eocene and Vigla Limestones; the higher $\mathrm{SiO}_{2}$ values may be related to biased results from the presence of clay minerals or microcrystalline silica. $\mathrm{P}_{2} \mathrm{O}_{5}$ and $\mathrm{SO}_{3}$ show a preferential accumulation mostly in calcites from skeletal grains and cement. Dolomites from the Triassic dolomitic rocks were analyzed from cement, skeletal and non skeletal (mainly micritized) grains and generally display coherent compositions. They are non-ferroan and their calcium and magnesium contents range between 30.19-32.11 wt $\%$ and 19.81-20.13 wt\%, respectively. They are characterized as Ca-rich, with a molar $\mathrm{CaCO}_{3}$ content ranging from 53.9 to 57.3 (Lumsden and Chimahusky, 1980; and Morrow, 1978, 1982a). 


\begin{tabular}{|c|c|c|c|c|c|c|c|c|c|c|c|c|c|c|c|}
\hline 安学 & $\subseteq$ & \multirow{4}{*}{ 急 } & : & & ' & & ' & 表 & , & 궁 & ' & ' & & $\begin{array}{l} \\
\end{array}$ & 䙳 \\
\hline $\bar{q} \overline{4}$ & $\stackrel{m}{s}$ & & ' & ' & ' & \&్రి & ' & 㕝 & , & สู & ' & ' & ' & ' & ب. \\
\hline E⿺辶 & $\leqq$ & & . & ' & , & ' & ' & 兽 & , & 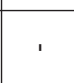 & ' & ' & ' & . & 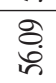 \\
\hline दे & $\Sigma$ & & 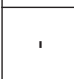 & ' & , & ' & ' & त्रु & , & 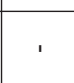 & ' & ' & . & . & त्ञ \\
\hline$\overline{\psi m}$ & $\frac{ \pm}{\infty}$ & \multirow{4}{*}{ 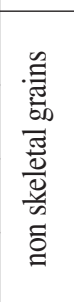 } & ' & ' & , & 莺 & ' & $\overrightarrow{\vec{c}}$ & , & ' & ' & ' & . & ' & $\vec{m}$ \\
\hline 安学 & 5 & & 名 & . & . & $\tilde{\tilde{\sigma}}$ & . & 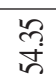 & वี & $\frac{\infty}{0}$ & ' & ' & ' & , & $\begin{array}{l}8 \\
0 \\
0 \\
n\end{array}$ \\
\hline$\frac{g}{m}$ & $\stackrel{m}{a}$ & & $\overrightarrow{g_{0}}$ & . & , & हू & , & $\stackrel{m}{H}$ & . & 旁 & ' & ' & ' & ల్రి & 茎 \\
\hline$\overline{4}$ & F & & , & . & , & ă & , & $\frac{5}{5}$ & . & శิ & ' & ' & . & 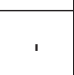 & $\vec{b}$ \\
\hline $\bar{q}$ & & \multirow{7}{*}{ 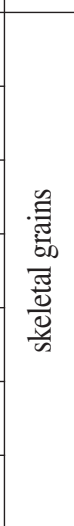 } & , & . & . & $\overline{\vec{\alpha}}$ & , & 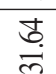 & . & $\frac{n}{0}$ & . & ' & r & , & 8 \\
\hline$\overline{\mathrm{z}} \mathrm{m}$ & 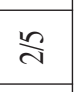 & & & $\stackrel{ \pm}{0}$ & . & 品 & . & 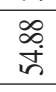 & శ్ & శ్ & . & ' & ' & $\bar{s}$ & 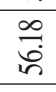 \\
\hline 安品 & $\stackrel{\sim}{\stackrel{2}{d}}$ & & ' & ' & . & ' & . & 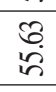 & . & , & . & ' & ' & , & $\begin{array}{l}\stackrel{B}{8} \\
\text { in }\end{array}$ \\
\hline 安扂 & $m$ & & . & . & . & สี & ' & $\begin{array}{l}\text { 足 } \\
\text { in }\end{array}$ & . & ন্d & ' & 웅 & ' & . & 售 \\
\hline द्र & in & & . & ' & ' & đ্تু & . & $\begin{array}{l}\text { ర్ } \\
\text { in }\end{array}$ & $\frac{9}{0}$ & ' & , & ' & ' & . & 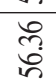 \\
\hline 安舫 & $\cong$ & & 路 & ' & . & ठ্. & . & $\begin{array}{l}\infty \\
\tilde{n} \\
\tilde{n}\end{array}$ & 명 & . & gू & . & gु & 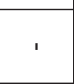 & 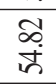 \\
\hline 安亭 & s & & , & . & . & . & . & $\begin{array}{l}\text { 采 } \\
\text { in }\end{array}$ & . & $\bar{\sigma}$ & के & . & . & , & $\begin{array}{l}8 \\
\text { in }\end{array}$ \\
\hline 兒向 & $\stackrel{+}{\mathrm{A}}$ & \multirow{5}{*}{ 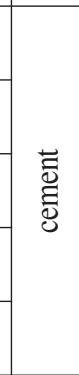 } & ' & . & ' & 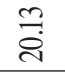 & . & $\underset{\text { స్ల }}{\overline{7}}$ & . & ' & . & . & ' & . & స్ \\
\hline $\bar{z} \bar{\lambda}$ & $\stackrel{一}{\%}$ & & . & ' & . & $\bar{s}$ & . & $\sqrt{7}$ & . & $\stackrel{\infty}{\stackrel{\infty}{0}}$ & ' & ' & ' & . & S্ \\
\hline$\xi \approx$ & $\Xi$ & & 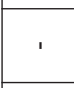 & . & . & $\tilde{S}$ & . & $\begin{array}{l}\text { के } \\
\text { हn }\end{array}$ & aे & ब্తి & ' & ' & . & . & 鿬 \\
\hline$\overline{4}$ & సి & & 명 & . & , & . & . & 恿 & $\bar{\delta}$ & 吉 & : & ' & . & ' & ì \\
\hline$\overline{4}$ & 㠻 & & ' & . & . & $\bar{y}$ & . & $\begin{array}{l}\text { 年 } \\
\text { 点 }\end{array}$ & 学 & \begin{tabular}{|c|}
$a$ \\
$g$
\end{tabular} & ' & ' & ' & , & 苚 \\
\hline 晏过 & $\stackrel{\circ}{\partial}$ & \multirow{5}{*}{ 总 } & ส্ & . & . & 悉 & . & $\begin{array}{l}\text { 鿖 } \\
\text { 号 }\end{array}$ & . & శ্ & . & . & ' & 零 & F్ \\
\hline$\xi \frac{g}{m}$ & ळे & & ' & ' & ' & $\stackrel{\infty}{0}$ & . & 䓵 & శี & $\frac{n}{0}$ & ' & ' & , & ' & 量 \\
\hline 安命 & $\stackrel{\stackrel{n}{\prime}}{s}$ & & ন্ড & . & . & $\stackrel{8}{a}$ & . & 赵 & $\tilde{a}$ & 吾 & . & . & ' & . & $\stackrel{9}{P}$ \\
\hline 安喓 & $\stackrel{m}{\Xi}$ & & - & . & 范 & 象 & . & $\ddot{\nabla}$ & $\frac{\infty}{0}$ & & . & . & ' & . & के \\
\hline 安亭 & สี & & $\overline{\text { g }}$ & 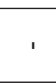 & . & 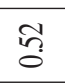 & . & $\vec{m}$ & . & $\stackrel{\circ}{\circ}$ & ' & . & & . & ڤั \\
\hline 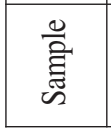 & 䍃 & 善 & 号 & ) & $\begin{array}{l}0 \\
\text { s. }\end{array}$ & $\frac{8}{2}$ & 总 & \% & 虽 & \begin{tabular}{l}
0 \\
\hdashline
\end{tabular} & $\stackrel{0}{\circ}$ & 8 & 옹 & $\underset{\sim}{\sim}$ & 急 \\
\hline
\end{tabular}




\section{Geochemistry}

Whole-rock geochemical analyses from the collected carbonate rocks are listed in Table 2. For comparison, the global average chemical composition of limestones (Mason and Moore, 1982) is also given. Our limestone samples have higher $\mathrm{CaO}$ and $\mathrm{Na}_{2} \mathrm{O}$ and lower $\mathrm{MgO}$ and $\mathrm{Sr}$ abundances relative to the global average limestone composition. Considering the chemical classification based on $\mathrm{CaCO}_{3}$ content (Oates, 1998), all samples are characterized as ultra-high calcium limestones $\left(\mathrm{CaCO}_{3}\right.$ $>97 \%)$, except for the sample AIT 37 which is a magnesian limestone $\left(\mathrm{CaCO}_{3}=80.23 \%\right)$. The total amount of impurities (sum of all oxides excluding $\mathrm{CaO}$ and $\mathrm{CO}_{2}$ ) for all the limestones except the dolomitic sample AIT 37, ranges between 0.27 and $1.65 \% . \mathrm{SiO}_{2}(0.03-0.93 \%)$ shows the highest concentrations in the Vigla limestones (Table 2), most likely due to the presence of minute silica grains and/or clay minerals in the carbonate matrix. This is compatible with the higher amounts of insoluble residual measured in these samples. All samples are poor in $\mathrm{MgO}(<1 \%)$, except for sample AIT 37 with high $\mathrm{MgO}$ content $(19.41 \%)$ due to the presence of dolomite. Samples AIT 34a,AIT $34 \mathrm{~b}$ and AIT 25a exhibit the highest Al concentrations, which along with high amounts in Si reflect the presence of detrital minerals in their carbonate matrix. Most biomicrites are rather rich in Fe most likely related to the occurrence of Fe-oxides and ilmenite, usually found together with clay minerals. $\mathrm{Na}, \mathrm{Mn}, \mathrm{K}$, and $\mathrm{P}$ are insignificant in most of the samples while $\mathrm{P}$ is primarily detected in the Senonian and Eocene limestones, probably attributed to the presence of apatite.

$\mathrm{Sr}$ is detected in all samples. Eocene and Senonian limestones are the most enriched samples in $\mathrm{Sr}$ (except for sample AIT 33 with $\mathrm{Sr}=181 \mathrm{ppm}$ ). The highest value is shown by the biomicrite sample AIT 34a (518 ppm) which contains also significant apatite amounts. The Pantokrator limestones, which contain the purest calcite, display the lowest $\mathrm{Sr}$ concentrations (78-114 ppm), except samples AIT 28a and AIT 24a, which are clearly richer in $\operatorname{Sr}$ (234 and 253, respectively). These two samples are also richer in $\mathrm{SiO}_{2}$ and $\mathrm{Al}_{2} \mathrm{O}_{3}$. The dolomitic sample AIT 37 has low Sr content compared to the rest analyzed carbonate rocks $(82 \mathrm{ppm})$. Sulfur content is fairly coherent displaying inconsiderable variations between $0.028-0.046 \mathrm{wt} \%$.

The trace elements As, Be, Br, Cd, Cs, Hf, Mo, Rb, Sb, Se, Ta, and Th amounts in the analyzed samples are mostly below detection limits. However, the studied limestones are generally enriched in $\mathrm{Ba}$, $\mathrm{Bi}, \mathrm{Co}$, and $\mathrm{Cu}$ compared to the global average limestone. The high $\mathrm{Ba}$ content in samples AIT 34a, AIT 34b and AIT 25a is most likely the result of the presence of barite in them. The Eocene and Vigla limestones demonstrate higher $\mathrm{Cu}$ values compared to the rest samples. The $\mathrm{U}$ abundance in sample AIT $37(5.3 \mathrm{ppm})$ is higher than the rest samples. Except for calcite, $\mathrm{Y}$ is commonly incorporated to apatite, replacing $\mathrm{Ca}$.

\section{Discussion and conclusions}

The analyzed, Triassic dolomitic rocks generally contain Ca-rich dolomite crystals with coherent compositions and $\mathrm{MgO}$ contents ranging from 19.81 to $20.13 \mathrm{wt} \%$. Ca-rich, fine-crystalline dolomites, similar to those observed in the analyzed sample from the Ionian Zone, are thought to be early diagenetic, near surface in origin and usually they are unassociated with evaporites (Tucker and Wright, 1990). However, it has been observed that evaporites occur at the lower members of these dolomitic rocks commonly forming diapyric domes (IGRS-IFP 1966; Underhill, 1988; Karakitsios, 1995). The timing of dolomitization as well as the mineralogy of the precursor carbonate are also important factors in determining the dolomite Sr content. Ancient dolomites have variable $\mathrm{Sr}$ contents, a few tens to hundreds of ppm is the typical range. Early dolomitization of marine carbonates will result in Sr-richer dolomites compared to those resulting from later dolomitization of stabilized 
Table 2. Whole-rock chemical analyses from the carbonate rocks of the Ionian Zone (-: below detection limits).

\begin{tabular}{|c|c|c|c|c|c|c|c|c|c|c|c|c|c|c|}
\hline \multirow{3}{*}{\begin{tabular}{|c|} 
Formation \\
Sample \\
\end{tabular}} & \multirow{2}{*}{\multicolumn{2}{|c|}{ Eocene }} & \multirow{2}{*}{\multicolumn{3}{|c|}{ Senonian }} & \multirow{2}{*}{\multicolumn{2}{|c|}{ Vigla }} & \multicolumn{7}{|c|}{ Pantokrator } \\
\hline & & & & & & & & \multicolumn{6}{|c|}{ Limestones } & \multirow{2}{*}{\begin{tabular}{|c|} 
Dolomites \\
AIT 37 \\
\end{tabular}} \\
\hline & AIT34A & AIT 34B & AIT $32 \mathrm{~A}$ & AIT 32B & AIT 33 & AIT $25 \mathrm{~A}$ & AIT 35 & AIT 26A & AIT 28A & AIT $31 \mathrm{~A}$ & AIT $31 \mathrm{~B}$ & \begin{tabular}{|l|l} 
AIT 36 \\
\end{tabular} & AIT 24A & \\
\hline \multicolumn{15}{|c|}{ Major elements wt $\%$} \\
\hline $\mathrm{SiO}_{2}$ & \begin{tabular}{|l|}
0.75 \\
\end{tabular} & 0.37 & 0.61 & 0.10 & 0.19 & 0.73 & 0.93 & 0.03 & 0.12 & 0.07 & 0.03 & 0.03 & 0.14 & 0.05 \\
\hline $\mathrm{TiO}_{2}$ & - & - & - & - & - & - & - & - & - & - & - & - & - & - \\
\hline $\mathrm{Al}_{2} \mathrm{O}_{3}$ & 0.24 & 0.12 & 0.25 & 0.03 & - & 0.20 & 0.21 & - & - & - & - & - & - & - \\
\hline $\mathrm{Fe}_{2} \mathrm{O}_{3}(\mathrm{~T})$ & 0.14 & 0.10 & 0.11 & 0.01 & - & 0.07 & 0.12 & - & - & - & - & - & - & - \\
\hline $\mathrm{MnO}$ & 0.04 & 0.03 & 0.04 & 0.02 & - & 0.01 & 0.02 & - & - & - & - & - & - & - \\
\hline $\mathrm{MgO}$ & 0.36 & 0.37 & 0.50 & 0.34 & 0.57 & 0.34 & 0.29 & 0.20 & 0.42 & 0.22 & 0.39 & 0.39 & 0.46 & 19.41 \\
\hline $\mathrm{CaO}$ & 55.30 & 54.39 & 53.55 & 54.43 & 54.28 & 55.25 & 54.13 & 55.70 & 56.01 & 55.84 & 55.35 & 54.89 & 56.05 & 33.04 \\
\hline $\mathrm{Na}_{2} \mathrm{O}$ & 0.08 & 0.06 & 0.04 & 0.05 & 0.05 & 0.07 & 0.05 & 0.04 & 0.05 & 0.07 & 0.07 & 0.05 & 0.05 & 0.12 \\
\hline $\mathrm{K}_{2} \mathrm{O}$ & 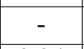 & - & 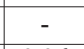 & 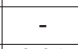 & - & 0.04 & - & - & - & - & 0.02 & - & - & 0.02 \\
\hline $\mathrm{P}_{2} \mathrm{O}_{5}$ & 0.04 & 0.05 & 0.06 & 0.01 & 0.02 & 0.02 & 0.02 & - & - & - & - & - & 0.01 & - \\
\hline LOI & 43.28 & 43.49 & 43.39 & 43.73 & 43.67 & 43.43 & 43.22 & 42.85 & 43.79 & 42.80 & 43.42 & 43.35 & 43.48 & 46.63 \\
\hline Total & 100.20 & 98.94 & 98.54 & 98.7 & 98.83 & 100.20 & 98.96 & 98.78 & 100.50 & 98.94 & 99.29 & 98.66 & 100.30 & 99.30 \\
\hline $\mathrm{CO}_{2}$ & 44.50 & 44.90 & 43.80 & 44.80 & 45.20 & 45.40 & 45.00 & 45.60 & 45.30 & 44.90 & 44.80 & 45.90 & 45.40 & 47.90 \\
\hline $\mathrm{CaCO}_{3}$ & 98.38 & 98.93 & 98.38 & 99.45 & 99.11 & 98.48 & 98.37 & 99.77 & 99.30 & 99.70 & 99.48 & 99.57 & \begin{tabular}{|c|}
99.23 \\
\end{tabular} & 80.23 \\
\hline \multicolumn{15}{|c|}{ Trace elements ppm } \\
\hline $\mathrm{S}(\%)$ & 0.037 & 0.046 & 0.038 & 0.039 & 0.034 & 0.039 & 0.034 & 0.028 & 0.034 & 0.029 & 0.043 & 0.034 & 0.043 & 0.041 \\
\hline $\mathrm{Cr}$ & 5 & 6 & 6 & - & 8 & 5 & - & 4 & 5 & - & 2 & 4 & 6 & - \\
\hline Co & 5 & 4 & 3 & 4 & 5 & 5 & 3 & 3 & 3 & 4 & 3 & 5 & 4 & 7 \\
\hline $\mathrm{Ni}$ & 5 & 2 & 4 & - & - & - & 1 & - & 1 & - & 1 & - & - & - \\
\hline $\mathrm{Cu}$ & 12 & 11 & 3 & 2 & 3 & 10 & 5 & - & 1 & 1 & 3 & - & 4 & 1 \\
\hline $\mathrm{Zn}$ & 7.0 & 3.0 & 5.0 & - & - & 4.0 & 5.0 & - & - & - & - & - & - & - \\
\hline $\mathrm{Rb}$ & 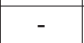 & - & - & - & - & - & - & - & - & - & - & - & - & - \\
\hline $\mathrm{Sr}$ & 518 & 439 & 415 & 367 & 181 & 191 & 122 & 78 & 234 & 79 & 108 & 114 & 253 & 82 \\
\hline $\mathrm{Y}$ & 7 & 5 & 9 & - & - & 8 & 4 & - & - & 2 & 6 & - & 2 & - \\
\hline $\mathrm{Zr}$ & - & - & 3.0 & - & - & 4.0 & - & - & - & - & 3.0 & - & - & - \\
\hline $\mathrm{Pb}$ & 8 & 10 & 8 & 10 & 7 & 9 & 9 & 9 & 8 & 8 & 6 & 8 & 9 & - \\
\hline $\mathrm{Ba}$ & 38 & 20 & 6 & - & 4 & 12 & 10 & - & 4 & - & - & 4 & 3 & 3 \\
\hline $\mathrm{V}$ & - & - & 9 & - & - & - & - & - & 7 & - & 19 & - & - & 8 \\
\hline Sc & 0.4 & 0.2 & 0.7 & 0.1 & 0.1 & 0.5 & 0.3 & - & - & - & - & - & 0.1 & - \\
\hline Th & - & - & - & - & - & - & - & - & - & - & - & - & - & - \\
\hline $\mathrm{Ta}$ & - & - & - & - & - & - & - & - & - & - & - & - & - & - \\
\hline $\mathrm{Hf}$ & - & - & - & - & - & - & - & - & - & - & - & - & - & - \\
\hline As & - & - & - & - & - & - & - & - & - & - & - & - & - & - \\
\hline Mo & - & - & - & - & - & - & - & - & - & - & - & - & - & - \\
\hline $\mathrm{Ag}$ & - & - & - & - & - & - & 1.0 & - & - & - & 0.5 & - & - & - \\
\hline $\mathrm{Cd}$ & - & - & - & - & - & - & & - & - & - & - & - & - & - \\
\hline $\mathrm{Hg}$ & - & - & - & - & - & - & - & - & - & - & - & - & - & - \\
\hline $\mathrm{Bi}$ & - & - & - & 5 & - & - & - & - & - & 4 & - & - & - & 9 \\
\hline $\mathrm{U}$ & - & - & 0.6 & - & - & - & - & - & 0.7 & - & 1.4 & - & - & 5.3 \\
\hline $\mathrm{Au}(\mathrm{ppb})$ & 11 & 12 & 8 & - & - & 29 & 25 & - & 8 & - & 20 & - & - & - \\
\hline $\mathrm{Be}$ & - & - & - & - & - & - & - & - & - & - & - & - & - & - \\
\hline $\mathrm{Br}$ & - & - & - & - & - & - & - & - & - & - & - & - & - & - \\
\hline Cs & - & - & - & - & - & - & - & - & - & - & - & - & - & - \\
\hline $\mathrm{Ir}$ & - & - & - & - & - & - & - & - & - & - & - & - & - & - \\
\hline $\mathrm{Sb}$ & - & - & - & - & - & - & - & - & - & - & - & - & - & - \\
\hline $\mathrm{Se}$ & - & - & - & - & - & - & - & - & - & - & - & - & - & - \\
\hline
\end{tabular}


marine carbonates composed of diagenetic low-Mg calcite (Tucker and Wright, 1990). However, based on dolomite stoichiometry and rock microstructure it is suggested that the low-Sr dolomites from the Ionian Zone are interpreted as early diagenetic and are related to dolomitization of original carbonate phases poor in aragonite skeletal components. Ancient dolomites have variable $\mathrm{Sr}$ contents, a few tens to hundreds of ppm is the typical range. Early dolomitization of marine carbonates will result in Sr-richer dolomites compared to those resulting from later dolomitization of stabilized marine carbonates composed of diagenetic low-Mg calcite (Tucker and Wright, 1990). However, based on dolomite stoichiometry and rock microstructure it is suggested that the low-Sr dolomites from the Ionian Zone are interpreted as early diagenetic and are related to dolomitization of original carbonate phases poor in aragonite skeletal components.

The Pantokrator limestones are the purest carbonate rocks of the Ionian zone, devoid of non-carbonate impurities. Mineral chemistry is also compatible with this fact since the analyzed calcites from the Pantokrator limestones are the purest in Ca phases. Whole-rock analyses suggest that most minor and trace elements are very low or below detection limits and the analyzed Pantokrator samples are clearly the most enriched in $\mathrm{CaO}$ relative to the rest samples. The microspars observed in the Pantokrator limestone samples are the result of aggrading neomorphism of the precursor carbonate mud.

The Vigla limestone belongs to the post-rift sequence of the Ionian Zone (Karakitsios, 1995). The nodular and bedded cherts found within the Vigla limestones indicate the change of the depositional conditions from neritic to pelagic and the evolution of the Ionian Zone from shallow-marine platform to a deep basin. The micrite matrix of the Vigla limestones is loaded with homogenously, distributed very-fine silica crystals, related also to their deep water depositional environment. Whole-rock geochemical results indicate that $\mathrm{SiO}_{2}$ contents are also higher than the limestones from the other formations, most likely due to the presence of minute silica grains and/or clay minerals in the carbonate matrix. This is consistent with the higher amounts of insoluble residue measured in these samples, and most likely reflects the pelagic depositional conditions which were prevailing during this period.

Most of the biomicrites from Eocene, Senonian and Vigla formations are rather rich in Fe, reflecting the occurrence of Fe-oxides. These opaque minerals are frequently usually found in association with clay minerals of clastic origin. The formation of the Senonian and Paleocene-Eocene limestones mark the post-rift period of the pre-orogenic evolution of the Ionian Zone, and correspond to depositional conditions where pelagic sedimentation (resulted in deposition of biomicrites) and clastic material influx from the basin margins and the neighboring zones (resulted in formation of brecciated lithotypes). The Eocene and Senonian limestones are the most enriched in Sr samples. Sr substitutes greatly for $\mathrm{Ca}$ in calcite; however, it is also a significant substitute for $\mathrm{Ca}$ and $\mathrm{Ba}$ in apatite and barite lattice, respectively. The highest $\mathrm{Sr}$ values are shown by the samples which contain also appreciable amounts of apatite and barite, therefore suggesting that calcite, apatite and barite contribute to the concentration of Sr. The low Sr contents in the Pantokrator limestone may be related to diagenetic loss of $\mathrm{Sr}$, and/or to a calcitic rather than an aragonitic original mineralogy, likely in an inner platform environment which are typically poor in aragonite and/or the absence of non carbonate minerals related to $\mathrm{Sr}$.

\section{References}

Aubouin, J., 1959. Contribution a l' etude géologique de la Grèce septentrional: les confins de l' épire et de la Thessalie, Ann. Geol. Pays Hell 10, 403. 
Bosellini, A., and Morsilli, M., 1997. A Lower Cretaceous drowning unconformity on the eastern flank of the Apulian Platform (Cargano Promontory, southern Italy), Cretaceous Research 18, 51-61.

B.P. Co. Ltd., 1971. The geological results of petroleum exploration in western Greece. The Geology of Greece, Institute for Geology and Subsurface Research, Athens, 73p.

Carr, D. D., Rooney, L. F., and Freas, R. C., 1994. Limestone and dolomite, Industrial Minerals and Rocks, AIME Soc, 605-609.

De Wever, P., 1975. Etude géologique des series apparaissant en fenêtre sous l' alloctone pindique (série de Tripolitz et série épimetamorphique de Zarouchola). Péloponnèse septentrional, Grèce, Thèse 3eme cycle, Université de Lille.

Degnan, P.J., 1992. Tectono-Sedimentary Evolution of a Passive Margin: The Pindos Zone of the NW Peloponnese, Greece. Unpublished PhD thesis, University of Endibourg.

Degnan, P.J. and Robertson, A.H.F., 1998. Mesozoic-early Tertiary passive margin evolution of the Pindos ocean (NW Peloponnese, Greece), Sedimentary Geology 117, 33-70.

Dunham, R.J., 1962. Classification of carbonate rocks according to depositional texture. In: W.E. Ham (ed.). Classification of carbonate rocks, Am. Assoc. Petroleum Geologists, Memoir 1, 108-121.

Fleury, J.J., 1980. Evolution d' un basin dans leur cadre alpin: les zones de Gavrovo-Tripolitze et du Pinde-Olonos, Soc. Géol.Nord.Spec. Publ. 4, 651.

Folk, R.L., 1959. Practical petrographic classification of limestones, Bull.Am. Ass. Petroleum Geologists 43, 1-38.

Folk, R.L., 1962. Spectral subdivision of limestone types. In: W.E. Ham (ed.), Classification of carbonate rocks, Am. Assoc. Petroleum Geologists, Memoir 1, 62-84.

IGRS-IFP, 1966. Étude geologique de l'Epire. Institute for Geology and Subsurface Research, Athens, $306 \mathrm{p}$.

Jones, G., 1990. Tectonostratigraphy and evolution of the Pindos Ophiolite and Associated Units, Northwest Greece, $P h D$. thesis, University of Endibourg.

Karakitsios, V., 1995. The influence of preexisting structure and halokinesis on organic matter preservation and trust system evolution in the Ionian basin, Northwestern Greece, AAPG Bullentin 79, 960-980.

Karakitsios, V., and Kolleti, L., 1992. Critical revision of the age of the basal Vigla limestones (Ionian Zone, western Greece), based on nannoplankton and calpionellids with paleogeographical consequences. In B. Hamrsmid and J. Young (eds), Proceedings of the Forth International Nannoplankton Association Conference, Prague 1991, Knihovnicka ZPN, 14a, vol. 1, 165-177.

Karakitsios, V., Tsikos, H., Van Breugel, Y., Bakopoulos, I., Koletti, L., 2004 Cretaceous oceanic anoxic events in western continental Greece, Bull of the Geol. Soc. Greece, XXXVI, 846-855.

Katsikatsos, G., 1992. The geology of Greece, University of Patras, 451.

Lumsden, D. N. and Chimahusky, J. S., 1980. Relationship between dolomite nonstoichiometry and carbonate facies parameters. In: Concepts and Models of Dolomitization (ED. by D. H. Zenger , J. B. Dunham and R. L. Ethington) Spec. Publ. Soc. econ. Paleont. Miner. 28, 123-137.

Mason, B. H. and Moore, C. B., 1982., Principles of Geochemistry, John Wiley, New York, 344.

Morrow, D. W., 1978. The influence of the $\mathrm{Mg} / \mathrm{Ca}$ ratio and salinity on dolomitization in evaporite basins, Bull. Can.petrol. Geol. 26, 389-392.

Morrow, D. W., 1982a. Diagenesis I. Dolomite-part I. The chemistry of dolomitization and dolomite precipitation, Geoscience Canada 9, 95-107.

Oates, J.A.H., 1998. Lime and Limestone. Chemistry and Technology, Production and Uses. Willey-VCH Verlang, Germany. 
Renz, C., 1955. Die vorneogene Stratigraphie der normal-sedimentaren Formationen Griechelan. Inst. Geol. Susurf. Res. Athens, 637.

Robertson, A.H.F., 1994. Role of the tectonic facies concept in orogenic analysis and its application to Tethys in the Eastern Mediterranean region, Earth. Sci. Rev. 37, 139-213.

Robertson, A.H.F., Clift, P.D., Degnan, P.J., and Jones, G., 1991. Palaeogeographic and palaeotectonic evolution of the Eastern Mediterranean Neotethys, Palaeog. Palaeocl. Palaeoecol., 87: 289-343.

Robertson, A.H.F., and Degnan, P.J., 1997. Kerassia Millia Complex evidence of a Mesozoic-Early Tertiary oceanic basin between the Apulian continental margin and the Parnassus carbonate platform in western Greece, Bull. Geol. Soc. Greece.

Smith, A.G., Hynes, A.J., Menzies, M., Nisbet, E.G., Price, I., Welland, M.J.P., and Ferrière, J., 1975. The stratigraphy of the Othris Mountains, estern central Greece: a deformed continental margin succession, Eclogae Geol. Helv. 86, 463-481.

Smith, A.G., Woodcock, N.H., and Naylor, M.A., 1979. The structural evolution of a Mesozoic continental margin, Othris Mountains, Greece, J. Geol. Soc. London 136, 589-603.

Tucker, E. M., and Wright V. P., 1990. Carbonate Sedimentology, Blackwell Science, 482, 370-381.

Underhill, J. R., 1988. Triassic evaporites and Plio-Quaternary diapirism in western Greece, Journal of the Geological Society, London 145, 269-282.

Zelilidis, A., Piper, D. J., Vakalas, I., Avramidis, P., and Getsos, K., 2003. Oil and Gas Plays in Albania: Do Equivalent Plays Exist in Greece?, Journal of Petroleum Geology 26, 29-48. 